J. Lake Sci. (湖泊科学), 2014, 26(2): 277-287

http: //www. jlakes. org. E-mail : jlakes@niglas.ac.cn

(C) 2014 by Journal of Lake Sciences

\title{
东巢湖湖滨农田生态拦截沟中浮游植物群落结构”
}

\author{
郭匿春 ${ }^{1}$, 马友华 ${ }^{1 * *}$, 李 妿 $^{2}$, 胡菊香 $^{3},{\text { 张 } \text { 震 }^{1} \text {, 何金铃 }}^{4}$ \\ ( 1 : 安徽农业大学资源与环境学院, 合肥 230036) \\ $(2$ : 安徽省环境科学研究院安徽省污水处理技术研究重点实验室,合肥 230061) \\ ( 3 : 水利部中国科学院水工程生态研究所水生生物学研究室, 武汉 430079) \\ ( 4 : 安徽农业大学生命科学学院, 合肥 230036)
}

\begin{abstract}
摘 要: 在巢湖市烔炀镇西宋村农田示范基地中建立生态拦截沟来处理农业生产排放的农业面源污水, 就生态拦截沟中 浮游植物丰度、生物量和群落结构进行了研究. 实验历时 6 个月, 研究中共检测到浮游植物 9 门 48 属 75 种. 研究发现尽 管农田生态拦截沟中的水生植被能有效削减水体中的氮、磷营养盐, 但对浮游植物群落结构产生的影响不大. 生态拦截 沟中主要藻类为绿藻、蓝藻和硅藻, 且出水口蓝藻所占比例较进水口有显著上升. 生态拦截前后浮游植物优势种类的变 化不大, 主要为蓝藻门的铜绿微囊藻 (Microcystis aeruginosa) 、绿藻门的微球衣藻 (Chlamydomonas microsphaera) 和硅藻门 的孟氏小环藻 (Cyclotell meneghiniana) 等. 藻类生物多样性研究表明生态拦截沟中的水体主要为清洁或塞污型水体, 仅在 夏季的 7 月份出现了轻微的水体污染. 典型对应分析发现, TN/TP 对浮游植物种类分布的解释度最高. 同时, 发现水体总 磷的对数、总溶解磷的对数与藻类的生物量呈正比, 而 $\mathrm{TN} / \mathrm{TP}$ 与藻类的生物量呈反比. 研究表明农田生态拦截沟尽管具 有削减农业氮、磷营养盐面源污染的作用, 但不能有效地降低水体中蓝藻的生物量. 农业面源污水中的藻类营养盐限制 主要为磷限制, 削减农田径流中的磷含量是控制巢湖流域水体富营养化和遏制蓝藻水华的关键环节.
\end{abstract}

关键词: 生态拦截沟;营养盐;浮游植物;藻类多样性指数;典范对应分析;巢湖

\section{Phytoplankton community in the ecological interception ditch approach to the eastern Lake Chaohu}

GUO Nichun ${ }^{1}$, MA Youhua ${ }^{1}$, LI Kun ${ }^{2}$, HU Juxiang ${ }^{3}$, ZHANG Zhen ${ }^{1} \&$ HE Jinling ${ }^{4}$

(1: Resources and Environment College, Anhui Agricultural University, Hefei 230036, P. R. China)

(2: Provincial Key Laboratory of Research on Wastewater Treatment Technology, Anhui Academy of Environmental Science Research, Hefei 230061, P. R. China)

(3: Institute of Hydroecology, Ministry of Water Resources and Chinese Academy of Sciences, Wuhan 430079, P. R. China)

(4: School of Life Siences, Anhui Agricultural University, Hefei 230036, P. R. China)

Abstract: The phytoplankton community in the ecological interception ditch of the farm demonstration base approach to the eastern Lake Chaohu were analyzed in a six months-experiments. About 75 species of phytoplankton were identified. The ecological interception ditch reduced the runoff of nitrogen and phosphorus significantly, but it didn' t change the phytoplankton community. Chlorophytes, Cyanophytes and Bacillariophytes were dominant in the ecological interception ditch. The proportion of Cyanophytes in phytoplankton community increased in the outlet contrast with the inlet. Microcystis aeruginosa, Chlamydomonas microsphaera and Cyclotell meneghiniana were main species in the ecological interception ditch. There are significant relationships between the biomass of phytoplankton and lg TDP, lg TP and TN/TP. The Simpson's diversity index of phytoplankton suggested the water quality of the ecological interception ditch was clean, only little polluted in July. Canonical corespondence analysis (CCA) exhibited the distribution of phytoplankton was mainly affected by TN/TP. Our results suggested macrophytes in ecological interception ditch re-

* 国家自然科学基金项目(31300395)、农业部农业生态环境保护项目(2110402-1177) 和公益性行业(农业)科研专 项项目 (201003014) 联合资助. 2013-01-16 收稿;2013-04-25 收修改稿. 郭匿春 (1980 ), 男,博士, 讲师; Email:Guonichun@ahau.edu.cn.

** 通信作者;E-mail: yhma@ ahau. edu.cn. 
duce the runoff of nitrogen and phosphorus, while didn't prevent the dominance of Cyanobacteria. The P-limitation of phytoplankton was the main factor affecting the growth of algae, a reduction of phosphorus would result in the control of algae and the cleanup of water quality.

Keywords: Ecological interception ditch; nutrients; phytoplankton; simpson's diversity index; CCA; Lake Chaohu

巢湖流域农业生产带来的大量氮、磷营养盐面源污染是造成巢湖水体富营养程度加剧和蓝藻水华频繁 暴发的主要原因 ${ }^{[1-2]}$. 以水生植被为主的湖滨生态湿地可以过滤和削减农业氮、磷营养盐面源污染, 降低巢 湖富营养化程度和净化巢湖流域水质 ${ }^{[1]}$. 通过以培植水生植物为主的生态拦截沟湿地削减农业面源污染和 控制藻类水华的机理主要有: 1) 水生植物具有与水体中的浮游植物直接竞争氮、磷营养盐的能力 ${ }^{[3]} ; 2$ ) 水生 植物由于个体大、生命周期长, 能够通过与藻类竞争光资源而影响藻类生长 $\left.{ }^{[4]} ; 3\right)$ 水生植物为水体中食浮游 植物的浮游动物提供庇护, 从而增加其澡类牧食率 $\left.{ }^{[5]} ; 4\right)$ 释放化感物质来抑制藻类的生长 ${ }^{[6-7]}$. 在降低富营 养化湖泊流域水体营养化程度和遏制蓝藻水华的生态修复工程中,水生植被生态拦截沟发挥了至关重要的 作用 ${ }^{[8-9]}$.

一般来讲, 浮游植物的丰度和生物量会随着水生态重建计划的实施而降低 ${ }^{[10-11]}$. 水质的改善和水生植 被的恢复也会对浮游植物的群落结构造成显著影响 ${ }^{[4]}$. 根据藻类的生存策略特点, 浮游植物的种类可划分 为 3 大类: C-invasive (进攻策略型) 、S-acquisitive (进取策略型) 和 R-attuning (协调策略型) ${ }^{[12]}$. 研究发现在实 施了水生态修复的水体中, $\mathrm{C}$ 类藻类 (如隐藻和硅藻) 可以取代 $\mathrm{S}$ 类藻类 (如蓝藻) 成为水体的优势种类 ${ }^{[13]}$. 而普通农田中的 S 类藻类——蓝藻种类和生物量均不高 ${ }^{[14]}$, 与农田相邻的富营养化水体常发生严重的蓝藻 水华 ${ }^{[15]}$, 生态拦截沟能否遏制蓝藻成为水体中的优势种类值得关注 ${ }^{[4]}$. 同时, 水生态修复过程中氮、磷营养 盐和氮磷比的变化对浮游植物群落结构的影响也引人关注 ${ }^{[16-18]}$. 另外, 浮游植物的生物多样性也常常用于 水体污染程度的评价, 但其变化常受多种指标的综合影响 ${ }^{[10]}$. 水生生态系统由藻型水体向草型水体转化过 程中常存在多种稳态, 水生植被类型和营养盐水平在这种稳态转换和稳态维持中具有重要作用 ${ }^{[19]}$. 通过对 巢湖周边生态拦截沟中浮游植物群落结构和生物多样性的研究, 有助于揭示藻型水体向草型水体转化过程 中水生植物和营养物质的作用, 并为巢湖流域水生生态系统结构的调整和蓝藻水华的控制提供理论依据.

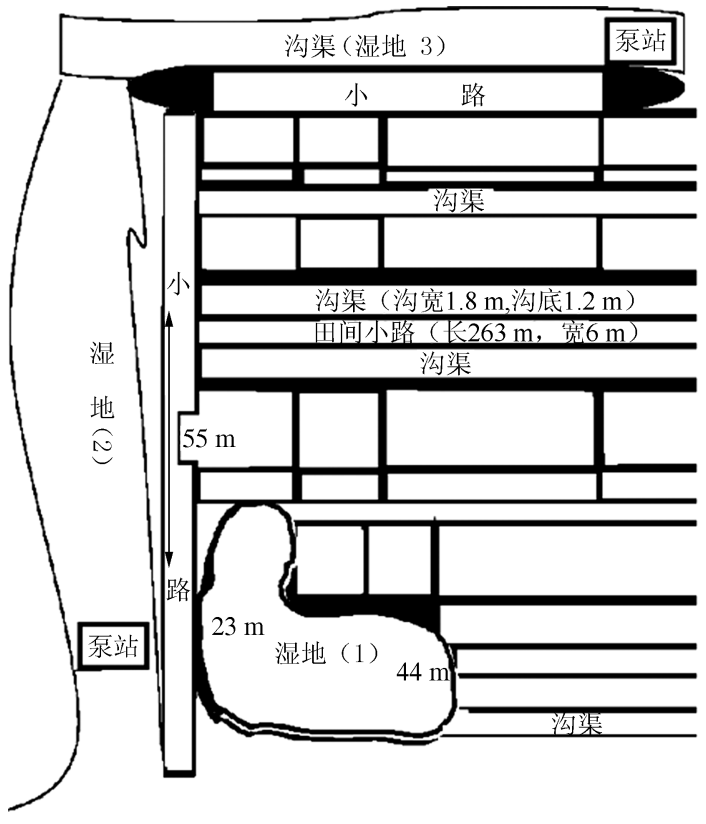

图 1 巢湖市烔炀镇农田生态示范基地示意图

Fig. 1 The location of the farmland demonstration base

本研究通过对农田生态拦截沟中浮游植物的 种类分布、生物量和生物多样性进行分析, 以期了 解农田生态拦截沟中浮游植物的群落结构和变化 趋势, 进而研究农田径流中的浮游植物群落变化 与农田生态拦截沟的不同区段、氮磷营养盐和水 生植物之间的联系, 探讨巢湖流域农田排放的农 业面源污水的水生态修复机理和水稳态维持 机制.

\section{1 材料与方法}

\section{1 研究地点}

实验区 $\left(31^{\circ} 39^{\prime} 59^{\prime \prime} \mathrm{N}, 117^{\circ} 40^{\prime} 48^{\prime \prime} \mathrm{E}\right)$ 位于安徽 省巢湖市烔炀镇西宋村中国农业部农业环境试验 站内, 实验区总面积约 $100000 \mathrm{~km}^{2}$ (图 1). 该区年 平均降水量在 $1000 \sim 1158 \mathrm{~mm}$ 之间, 年平均气温 为 $16.1^{\circ} \mathrm{C}$, 多年平均日照时数为 $2170.1 \mathrm{~h}$, 日照百 分率为 $49.0 \%$, 辐射总量为 $499092 \mathrm{~J} / \mathrm{cm}^{2}$, 无霜期 为 $263 \mathrm{~d}$, 多年平均年蒸发量为 $1124.4 \mathrm{~mm}$. 风速 为 $4.1 \mathrm{~m} / \mathrm{s}$, 盛行东风和东南风, 频率为 $30 \%$. 冬季 多东南风和西南风, 夏季多偏南风; 平均每年 8 级 
以上大风日数为 $18.8 \mathrm{~d}$, 历史最大风速为 $34.0 \mathrm{~m} / \mathrm{s}$. 属于北亚热带湿润季风气候区. 当地海拔高度一般在 $400 \sim 500 \mathrm{~m}$, 相对高差一般在 $100 \mathrm{~m}$ 以内. 土地利用形式以山地、水田和果园为主, 其中耕地约占总土地面积 的 $60 \%$. 主要农作物为水稻和小麦. 试验区每年施用化肥的剂量约为 $167 \mathrm{~kg} / \mathrm{hm}^{2}$, 主要施用种类为尿素和缓 施肥. 农药累计施用剂量约为 $670 \mathrm{ml} / \mathrm{hm}^{2}$.

\section{2 农田生态拦截沟渠设计}

在研究区选取两条沟岸经人工硬化整治的 $263 \mathrm{~m}$ 直型稻田排水沟, 水深一般为 $30 \mathrm{~cm}$ 左右, 水流速度较 慢, 一般在 $20 \sim 30 \mathrm{~cm} / \mathrm{s}$ 以内. 沟上口宽 $1.8 \mathrm{~m}$, 沟底宽 $1.2 \mathrm{~m}$, 沟高 $0.6 \mathrm{~m} .2012$ 年 4 月开始种植植物, 沟顶种 植 3 种冠幅 $60 \mathrm{~cm}$ 灌木: 红花聯木、红叶石楠和冬青卫矛, 株距 $1.5 \mathrm{~m}$, 间隔种植, 红绿相间; 两侧为 $50 \mathrm{~cm}$ 宽 黑麦草草坪. 沟内两侧壁种植两种小型藤本植物: 常春藤和络石, 株距 $30 \mathrm{~cm}, 5$ 株间种; 沟底种植多年生水生 植物, 选取物种包括: 荠白、石菖蒲、水芹、菱角和刺苦草 5 种植物 (处理) (图 2), 每种植物作为一个处理 (单 作), 设置两个重复, 共计 10 个小区, 随机排列在试验沟渠之中. 选取 $D_{1} 、 D_{2} 、 D_{3} 、 D_{4} 、 D_{6} 、 D_{7} 6$ 大种植区采样, 每一种植区长度从 $40 \sim 50 \mathrm{~m}$ 不等. 每月采样两次, 采样点分别为 $\mathrm{D}_{2-1} 、 \mathrm{D}_{2-2} 、 \mathrm{D}_{2-3} 、 \mathrm{D}_{3-1} 、 \mathrm{D}_{3-2} 、 \mathrm{D}_{4-2} 、 \mathrm{D}_{6}$ 和 $\mathrm{D}_{7} 8$ 个 采样点. 其中, $\mathrm{D}_{6}$ 和 $\mathrm{D}_{7}$ 采样点作为生态拦截沟的进水口和出水口采样点, 其余采样点设置在不同的水生植物 培植区中.

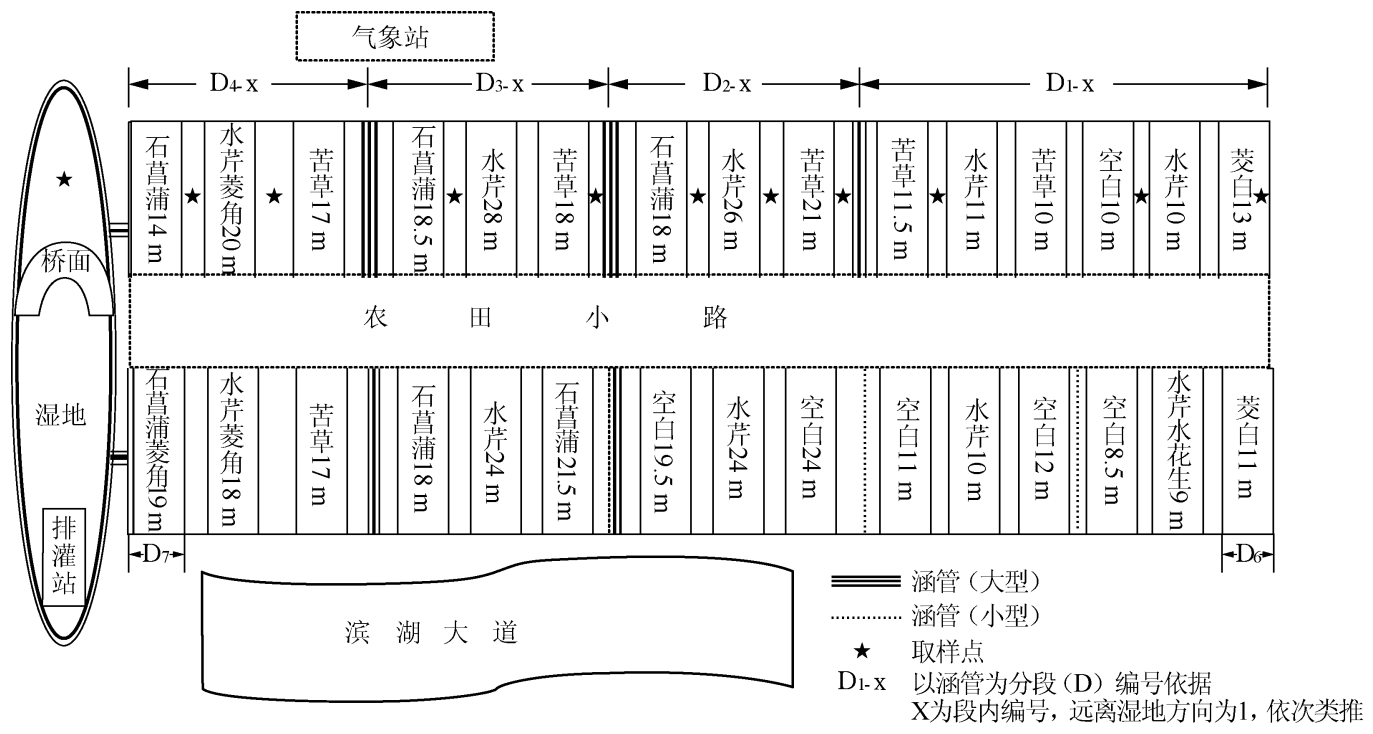

图 2 巢湖市烔炀镇农田生态示范基地植物布置和取样编号

Fig. 2 The sampling sites of the ecological interception ditch in the farmland demonstration base

\section{3 水体营养盐分析}

总磷 (TP) 浓度由未过滤的水样经 $\mathrm{K}_{2} \mathrm{~S}_{2} \mathrm{O}_{8}+\mathrm{NaOH}$ 消化成磷酸盐之后用钼锑抗比色法 ${ }^{[20]}$ 测定. 在消化 总磷的同时, 总氮 $(\mathrm{TN})$ 被消化成硝酸盐后在 $220 \mathrm{~nm}$ 处测定吸光值, 硝态氮 $\left(\mathrm{NO}_{3}^{-}-\mathrm{N}\right)$ 浓度通过自动化的 Korolev/Cadmium 还原法测定. 铵态氮 $\left(\mathrm{NH}_{4}^{+}-\mathrm{N}\right)$ 浓度用纳氏试剂分光光度法测定, 总溶解磷 ( TDP) 浓度用 $0.45 \mu \mathrm{m}$ 孔径的 GF/C膜过滤后的水样经钼锑抗比色法测定.

\section{4 浮游植物的检测}

用于浮游植物检测的 $500 \mathrm{ml}$ 混合水样经 $1 \%$ 的鲁哥试剂固定后, 在沉淀柱内重力沉淀 $48 \mathrm{~h}$, 弃去上清 液, 浓缩液收集定容到 $50 \mathrm{ml}$, 加数滴福尔马林保存. 定量计数在 $10 \times 40$ 倍显微镜视野下进行, 每个样本计数 两次, 每次计数在 100 500 个视野, 两次计数误差在 15\% 以上时, 重复计数标本. 对于样本中的群体, 如微 囊藻群体, 在计数前经超声波破碎成单个细胞后再进行计数. 浮游植物的鉴定主要参照文献 [ 21$]$, 浮游植物 生物量的估算及优势种大小测量参考金相灿等的方法 ${ }^{[22]}$. 


\section{5 浮游植物生物多样性计算}

选用 Shannon-Wiener 多样性指数 $\left(H^{\prime}\right) 、$ Pielou 均匀度指数 $(J)$ 和 Margalef 种类丰富度指数 $(d)$ 从不同侧 面反映生态拦截沟中浮游植物的多样性, 并进行水质评价, 公式如下:

$$
\begin{gathered}
H^{\prime}=-\sum_{i=1}^{S}\left(n_{i} / N\right) \log _{2}\left(n_{i} / N\right) \\
J=H^{\prime} / \log _{2} S \\
d=(S-1) / \ln N
\end{gathered}
$$

式中, $S$ 为总种数, $n_{i}$ 为第 $i$ 种的个体数量, $N$ 为样品中生物总个体数量.

\section{6 数据分析}

利用 CANOCO 4.5 软件, 采用典范对应分析 (CCA) ${ }^{[23]}$ 分析功能类群与环境变量之间的对应关系. CCA 双序图 (Biplot) 将样区排序、物种排序及环境因子排序表现在同一图上, 其中点代表浮游植物种类, 环境因子的变异方向则以箭头表示, 而箭头的长短则表示该一环境因子的影响程度. 运用 SPSS17.0 软件 进行方差分析 (ANOVA), 分析结果达到统计显著水平 $(P<0.05)$ 的再进行 Duncan's 多重比较. 采用 Excel 软件作图.

\section{2 结果}

\section{1 营养盐变化}

实验期间水体中各采样点主要营养盐指标的测定结果见表 1 . 实验期间, 通过对生态拦截沟进水口 $\left(\mathrm{D}_{6}\right)$ 和出水口 $\left(\mathrm{D}_{7}\right)$ 营养盐含量进行对比发现, 除 $\mathrm{NH}_{4}^{+}-\mathrm{N}$ 略有上升以外, 其他形态的营养盐浓度在经生态 沟拦截后均呈下降趋势, 其中 TDP 的削减幅度最高 (削减率为 $49.71 \%$ ), 而 N、P 的去除效率均高于 $10 \%$. 除 去生态拦截沟的进水口和出水口, 生态拦截沟中的 $\mathrm{TN}$ 平均浓度为 $1.540 \mathrm{mg} / \mathrm{L}, \mathrm{NO}_{3}^{-}-\mathrm{N}$ 平均浓度为 0.588 $\mathrm{mg} / \mathrm{L}, \mathrm{NH}_{4}{ }^{+}-\mathrm{N}$ 平均浓度为 $0.294 \mathrm{mg} / \mathrm{L}$, TP 平均浓度为 $0.114 \mathrm{mg} / \mathrm{L}$, TDP 平均浓度为 $0.038 \mathrm{mg} / \mathrm{L}$. 实验结束 时, 苦草处理组的 $\mathrm{NH}_{4}^{+}-\mathrm{N} 、 \mathrm{TN}$ 和 TP 浓度与其他水生植物处理组之间的差异达到了显著水平 $(P<0.05)$. 沉 水植物吸收和生物脱氮是苦草处理组 $\mathrm{N}$ 和 P 高去除率的主要原因. 生态拦截沟系统对 N 、 P 不同程度的去除 使得水体氮磷比 (TN/TP) 升高. 生态拦截沟进出水口的 TN/TP 一直维持在 10 左右, 低于生态拦截沟中段的 水生植物处理区 $\mathrm{TN} / \mathrm{TP}$, 均值为 13.87 .

表 1 实验期间生态拦截沟各采样点营养盐平均浓度

Tab. 1 The average concentration of nutrients in the ecological interception ditch

\begin{tabular}{ccccccc}
\hline 采样点 & $\mathrm{TN} /(\mathrm{mg} / \mathrm{L})$ & $\mathrm{NO}_{3}^{-}-\mathrm{N} /(\mathrm{mg} / \mathrm{L})$ & $\mathrm{NH}_{4}^{+}-\mathrm{N} /(\mathrm{mg} / \mathrm{L})$ & $\mathrm{TP} /(\mathrm{mg} / \mathrm{L})$ & $\mathrm{TDP} /(\mathrm{mg} / \mathrm{L})$ & $\mathrm{TN} / \mathrm{TP}$ \\
\hline $\mathrm{D}_{2-1}$ & 1.549 & 0.590 & 0.203 & 0.113 & 0.043 & 13.666 \\
$\mathrm{D}_{2-2}$ & 1.472 & 0.583 & 0.282 & 0.125 & 0.040 & 11.733 \\
$\mathrm{D}_{2-3}$ & 1.434 & 0.553 & 0.331 & 0.114 & 0.035 & 12.627 \\
$\mathrm{D}_{3-1}$ & 1.473 & 0.592 & 0.316 & 0.107 & 0.033 & 13.760 \\
$\mathrm{D}_{3-2}$ & 1.463 & 0.580 & 0.236 & 0.088 & 0.027 & 16.597 \\
$\mathrm{D}_{4-2}$ & 1.846 & 0.630 & 0.395 & 0.124 & 0.050 & 14.836 \\
$\mathrm{D}_{6}$ & 1.615 & 0.836 & 0.197 & 0.155 & 0.083 & 10.431 \\
$\mathrm{D}_{7}$ & 1.392 & 0.686 & 0.217 & 0.137 & 0.042 & 10.153 \\
\hline
\end{tabular}

\section{2 浮游植物种类组成}

在 2 条生态拦截沟的 8 个采样点进行了 12 次采样,共鉴定出浮游植物 9 门 48 属 75 种 (表 2). 其中绿 藻门种类最多, 总计 31 种, 占种类总数的 $41.33 \%$; 蓝藻门和硅藻门次之, 分别为 19 种和 13 种, 占种类总数 的 $25.33 \%$ 和 $17.33 \%$; 裸藻门 4 种, 占种类总数的 $5.33 \%$; 隐藻门、甲藻门和金藻门较少, 分别为 3 种、1 种 和 1 种, 仅占总数的 $4.0 \% 、 1.33 \%$ 和 $1.33 \%$. 当稻田面源污水排人生态拦截沟中后, 浮游植物的丰度和生物 
量由于底质、流动性、水生生物群落等综合环境的骤变而出现了两次高峰, 分别为 5 月上旬和 8 月下旬, 丰度 分别为 $1.24 \times 10^{6}$ 和 $1.94 \times 10^{6}$ cells $/ \mathrm{L}$, 生物量分别为 3.93 和 $5.50 \mathrm{mg} / \mathrm{L}$. 浮游植物丰度和生物量的两次低 谷分别出现在 6 月上旬和 9 月下旬, 丰度分别为 $2.02 \times 10^{5}$ 和 $2.42 \times 10^{5}$ cells/ $\mathrm{L}$, 生物量分别为 1.62 和 $1.82 \mathrm{mg} / \mathrm{L}$. 浮游植物丰度组成主要为蓝藻门 (最高达 $1.72 \times 10^{6} \mathrm{cells} / \mathrm{L}$ ), 而生物量最大的为绿藻门 (最高达 $3.04 \mathrm{mg} / \mathrm{L}$ ), 均出现在 8 月下旬. 生态拦截沟中浮游植物丰度和生物量在整个实验期间总体呈上升趋势 (图 3 ). 实验期间, 进水口浮游植物平均丰度为 $4.62 \times 10^{5} \mathrm{cells} / \mathrm{L}$, 而出水口浮游植物平均丰度为 $7.14 \times 10^{5}$ cells $/ \mathrm{L}$, 生物量也由 $2.12 \mathrm{mg} / \mathrm{L}$ 上升到 $3.56 \mathrm{mg} / \mathrm{L}$. 农田污水中浮游植物丰度和生物量经生态拦截均未发生显著下 降(图 4).

\section{表 2 生态拦截沟中浮游植物名录}

Tab. 2 List of phytoplankton in the ecological interception ditch

\begin{tabular}{|c|c|c|c|}
\hline 蓝藻门 & 绿藻门 & 实球藻属 (Pandorina) & 硅藻门 \\
\hline 微囊藻属( Microcystis) *** & 衣藻属 (Chlamydomonas) *** & 纤维藻属 (Ankistrodesmus) ${ }^{*}$ & 直链藻属 (Melosira) $)^{* * *}$ \\
\hline 束丝藻属 (Aphanizomenon) & 小球藻属 $($ Chlorella $) *$ & 棘球藻属 (Echinosphaerella) & 小环藻属 $(\text { Cyclotella })^{* * * *}$ \\
\hline 鱼腥藻属 (Anabaena) & 空球藻属 (Eudorina) * & 微孢藻属 (Microspora) & 舟形藻属 (Navicula) ** \\
\hline 颤藻属 (Oscillatoria) *** & 卵囊藻属( Oocystis) ** & 网球藻属 ( Dictyosphaerium) & 双菱藻属 (Surirella) * \\
\hline 蓝纤维藻属 ( Dactylococcopsis) & 盘星藻属 (Pediastrum) * & 蹄形藻属 (Kirchneriella) & 星杆藻属( Asterionella) \\
\hline 席藻属 ( Phormidium) & 角星鼓藻属 (Staurastrum) & 金藻门 & 针杆藻属 $(\text { Synedra })^{* * *}$ \\
\hline 项圈藻属 (Anabaenpsis) & 鼓藻属( Cosmarium) & 雉囊藻属 ( Dinobryon) * & 脆杆藻 (Fragilaria) \\
\hline 色球藻属 (Chroococcus) * & 栅藻属 $($ Scenedesmus $) *$ & 隐藻门 & 桥弯藻属 (Cymbella) \\
\hline 腔球藻属 (Coelosphaerium) *** & 韦氏藻属 (Westella) * & 隐藻属 (Cryptomonas) ** & 曲壳藻属 (Achnanthes) ** \\
\hline 隐球藻属 (Aphanocapsa) & 十字藻属(Crucigenia)* & 蓝隐藻属 (Chroomonas) & 裸藻门 \\
\hline 粘球藻属 (Gloeocapsa) & 四角藻属 (Tetraëdron) **** & 甲藻门 & 裸藻属 $($ Euglena $) *$ \\
\hline 平列藻属 (Merismopedia) & 集星藻属 (Actinastrum) & 角甲藻属 (Ceratium) & \\
\hline 黄藻门 & 空星藻属 (Coelastrum) *** & 多甲藻属 (Peridinium) * & \\
\hline 黄丝藻属 $($ Tribonema $) *$ & 新月藻属 $\left(\right.$ Closterium) *** $^{*}$ & 裸甲藻属 (Gymnodinium) & \\
\hline
\end{tabular}

$* * *$ 表示生物量为 $0.1 \sim 1.0 \mathrm{mg} / \mathrm{L} ; * *$ 表示生物量为 $0.01 \sim 0.10 \mathrm{mg} / \mathrm{L} ; *$ 表示生物量为 $0.001 \sim 0.01 \mathrm{mg} / \mathrm{L}$.

a

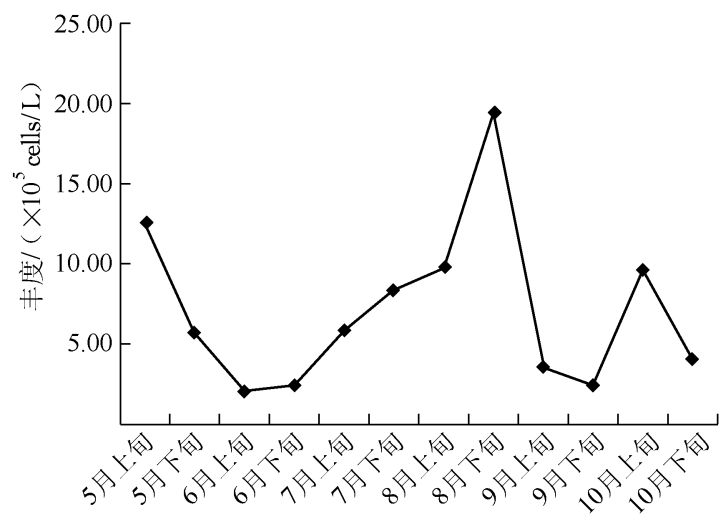

b

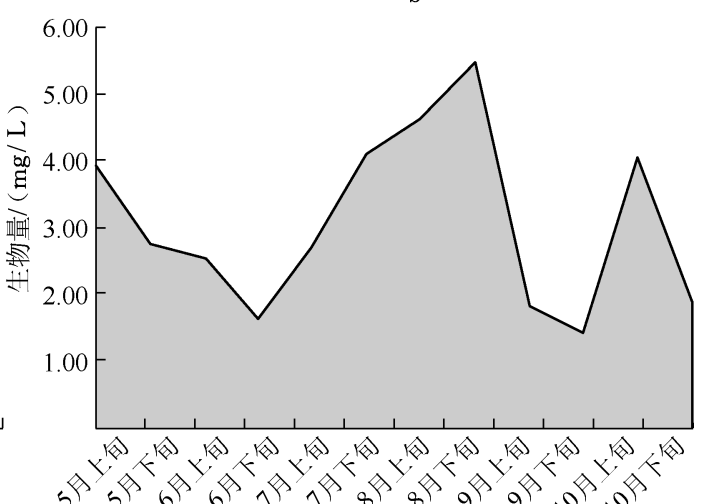

图 3 农田生态拦截沟中浮游植物丰度 (a) 与生物量 (b) 月变化

Fig. 3 Monthly changes of phytoplankton density(a) and biomass(b)in the ecological interception ditch

\section{3 浮游植物的群落演替}

随着浮游植物丰度和生物量的变化, 浮游植物的群落结构也有一定的变化. 其中, 绿藻门在生态拦截沟 中形成全阶段优势. 研究进行过程中,生态拦截沟中浮游植物群落结构变化趋势较为一致: 蓝藻门、绿藻门 

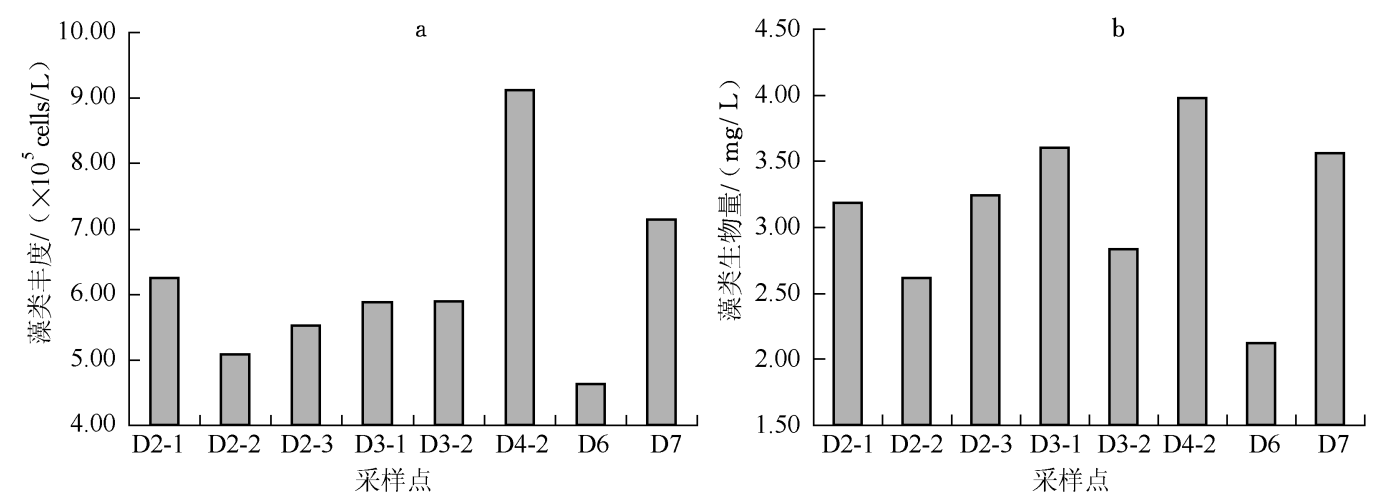

图 4 农田生态拦截沟中各采样点浮游植物丰度 (a) 与生物量 $(\mathrm{b})$

Fig. 4 Spatial distribution of phytoplankton density (a) and biomass (b) in the ecological interception ditch

和硅藻门一直在浮游植物群落中占据优势地位. 生态拦截过程中, 蓝藻门对藻类整体丰度的贡献率变化较 大, 由 $16.20 \%$ 上升到 $22.43 \%$; 绿藻门的贡献率由 $55.75 \%$ 下降到 $50.43 \%$; 硅藻门对整体丰度的贡献率波 动不大, 由 $24.10 \%$ 上升至 $26.24 \%$ ( 图 5 ). 研究结果表明, 生态拦截沟不能遏制蓝藻在浮游植物群落结构中 比重的上升.
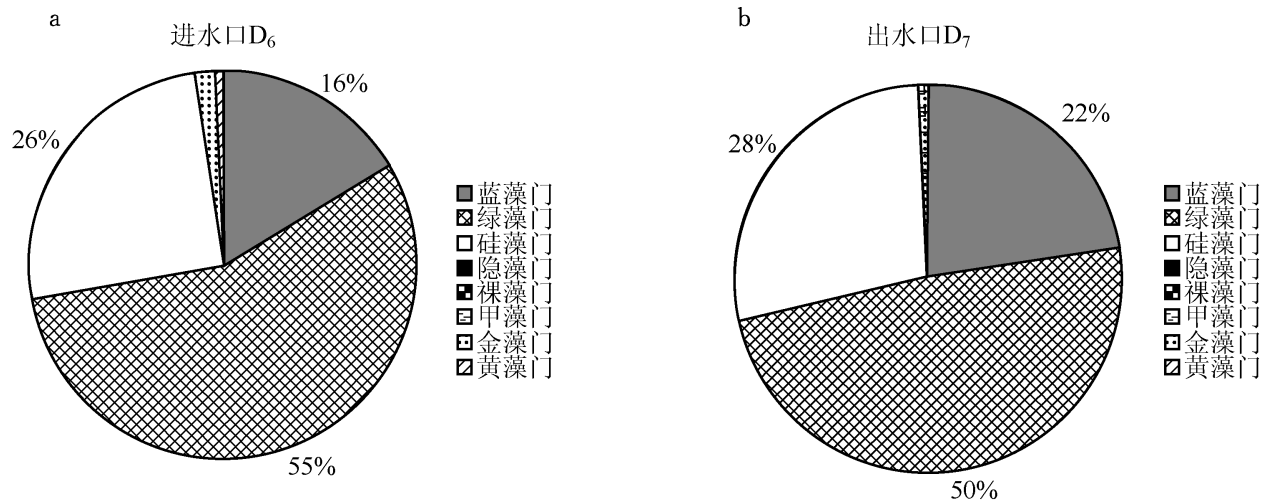

图 5 生态拦截沟进水口 (a) 和出水口 (b) 浮游植物群落结构对比

Fig. 5 The comparison of phytoplankton community in the water $\operatorname{inlet}(\mathrm{a})$ and the water outlet (b) of the ecological interception ditch

\section{4 浮游植物的优势种类变化与生态分类}

浮游植物优势种类的变化不大, 实验开始时农田排放污水中浮游植物的优势种为蓝藻门的铜绿微囊藻 (Microcystis aeruginosa)、弱细颤藻 (Oscillatoria tenuis) 和不定腔球藻 (Coelosphaerium dubium), 绿藻门的小球 藻 (Chlorella vulgaris) 和硅藻门的孟氏小环藻 (Cyclotella meneghiniana). 而生态拦截后, 生态拦截沟出水口浮 游植物的优势种类主要有: 蓝藻门的铜绿微囊藻, 绿藻门的微球衣藻 (Chlamydomonas microsphaera)、微小四 角藻 (Tetraedron minimum) 和小新月藻 (Closterium venus), 硅藻门的颗粒直链藻 (Melosir granulata)、孟氏小 环藻和针杆藻 (Synedra ulna), 隐藻门的啮蚀隐藻 (Cryptomonas erosa). 农田生态拦截沟中平均水深约 $30 \mathrm{~cm}$, 且易受农田排灌等生产活动的影响, 发生水体物理混合. 依据藻类对生态拦截沟的适应性, 农田生态拦截 沟中藻类的 9 个优势种类分属 3 种生态策略类型的 8 个优势功能族群 $(A 、 D 、 G 、 J 、 M 、 P 、 S 、 Y)$, 其中 A、D、 $\mathrm{G} 、 \mathrm{~J}$ 族藻类属 $\mathrm{C}$ 类进攻策略型藻类, $\mathrm{M}$ 族藻类属 $\mathrm{S}$ 类进取策略型藻类, $\mathrm{P} 、 \mathrm{~S} 、 \mathrm{Y}$ 族藻类属 $\mathrm{R}$ 类协调策略型 藻类 (表 3 ). 
表 3 生态拦截沟中浮游植物优势类群的特点 ${ }^{[31]}$

Tab. 3 Trait-separated functional groups of dominant phytoplankton species in the ecological interception ditch

\begin{tabular}{|c|c|c|c|c|c|}
\hline 族群 & 栖息水体 & 代表种类 & 耐受性 & 敏感度 & 属类 \\
\hline A & $\begin{array}{l}\text { 洁净, 常发生良好混合, 营养水 } \\
\text { 平低 }\end{array}$ & 小环藻属 & 氮缺乏 & $\mathrm{pH}$ 上升 & $\mathrm{C}$ \\
\hline $\mathrm{D}$ & 浅, 高度混浊的水体, 包括河流 & 针杆藻属 & 水体流动 & 营养耗尽 & $\mathrm{C}$ \\
\hline G & 短期存在的营养丰富水柱 & 空球藻属 & 高光照 & 缺乏营养 & $\mathrm{C}$ \\
\hline $\mathrm{J}$ & 浅, 富营养的湖泊、池塘和河流 & 衣藻属、四角藻属 & & 低光照强度 & $\mathrm{C}$ \\
\hline M & 轻度富营养水体的昼夜混合水层 & 微囊藻属 & 高度孤立水体 & 水体流动, 总光照低 & $\mathrm{S}$ \\
\hline $\mathrm{P}$ & 富营养水体的表层 & 新月藻属 & 光照强度弱和碳缺乏 & 分层, $\mathrm{Si}$ 耗尽水体 & $\mathrm{R}$ \\
\hline $\mathrm{S}$ & 混浊的混合水层 & 颤藻属 & 高光照强度 & 水体流动 & $\mathrm{R}$ \\
\hline $\mathrm{Y}$ & 小型的富营养水体 & 隐藻属 & 低光照强度 & 动物吞噬 & $\mathrm{R}$ \\
\hline
\end{tabular}

\section{5 生态拦截沟中浮游植物与营养盐变量的 CCA 排序分析}

CCA 排序分析将生态拦截沟中所有的营养盐变量 $\left(\mathrm{TN} 、 \mathrm{NO}_{3}^{-}-\mathrm{N} 、 \mathrm{NH}_{4}^{+}-\mathrm{N} 、 \mathrm{TP} 、 \mathrm{TDP} 、 \mathrm{TN} / \mathrm{TP}\right)$ 对浮游植物种类 分布的影响都选人分析. CCA 第一排序轴和第二排序轴 的特征值 (eigenvalue) 分别为 0.210 和 0.130 , 两轴累计变 异百分率 (cumulative percentage variance) 解释了种类数据 的 $21.28 \%$, 解释了种类一营养盐关系的 $35.4 \%, \mathrm{CCA}$ 分析 认为 8 个优势类群与 6 个环境变量之间的相关性不显著. 向前选择法 (forward selection) 分析了这 6 个环境变量对 浮游植物种类分布的独立影响. 结果表明, 最重要的环境 因子是 $\mathrm{TN} / \mathrm{TP}$, 解释了总变异的 $16 \%$, 其次是 $\mathrm{TDP}$ (14\%) 、 TP( 11\%)、 $\mathrm{NH}_{4}^{+}-\mathrm{N}(14 \%) 、 \mathrm{NO}_{3}^{-}-\mathrm{N}(11 \%)$ 和 $\mathrm{TN}$ $(4 \%)$ ( 图 6). 大部分藻类如 Microcystis、Cyclotell 等均位于 CCA 第一排序轴左侧 (图 6), 表明其分布受 TDP 的正面 影响, 而受 TN/TP 的负面影响.

\section{6 浮游植物的生物多样性变化}

通过 $H^{\prime} 、 J$ 和 $d$ 分析了生态拦截沟中各采样点和各月 份浮游植物的物种多样性、种类均匀度和种类丰富度的变 化 (表 4 和表 5 ). 结果表明, 实验期间, 荠白、苦草、水芹、 石菖蒲种植区中水生浮游植物 $H^{\prime}$ 之间差异均不显著 $(P$ $>0.05)$. 生态拦截沟中 7 月份的 $H^{\prime} 、 J$ 和 $d$ 显著低于其 他月份 $(P<0.05)$.

\section{7 浮游植物生物量与环境因子的相关性分析}

农田生态拦截沟中浮游植物生物量与 $\lg \mathrm{TP}$ 呈显著 的正相关关系 $(P<0.05)$, 与 $\lg$ TDP 也呈显著的正相关 关系 $(P<0.05)$, 与 $\mathrm{TN} / \mathrm{TP}$ 呈显著的负相关关系 $(P<$ $0.05)$, 与 $\lg \mathrm{TN}$ 没有显著的相关关系 $(P>0.05)$ ( 图 7 ). 由此可见, 在生态拦截沟中水生植物生长期间, 浮游植物 总生物量主要受水体中磷含量的限制, 而受水体中氮含 量影响不大.

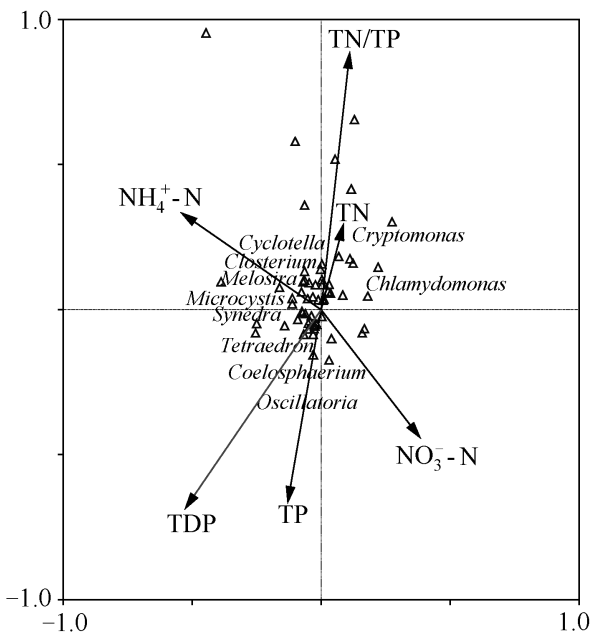

图 6 生态拦截沟中浮游植物优势功能 类群与环境变量的双序图

Fig. 6 Species-environment biplot of the ecological interception ditch

表 4 生态拦截沟中 $H^{\prime} 、 J$ 和 $d$ 的月变化

Tab. 4 The monthly dynamic of $H^{\prime}, J$ and $d$ in the ecological interception ditch

\begin{tabular}{cccc}
\hline & $H^{\prime}$ & $J$ & $d$ \\
\hline 5 月 & 3.57 & 0.67 & 2.85 \\
6 月 & 4.54 & 0.82 & 3.73 \\
7 月 & 3.08 & 0.58 & 2.57 \\
8 月 & 3.58 & 0.66 & 3.05 \\
9 月 & 3.51 & 0.65 & 3.29 \\
10 月 & 3.41 & 0.63 & 3.20 \\
\hline
\end{tabular}


表 5 农田生态拦截沟中不同采样点 $H^{\prime} 、 J$ 和 $d$ 比较

Tab. 5 The $H^{\prime}, J$ and $d$ of different sampling sites in the ecological interception ditch

\begin{tabular}{ccccccccc}
\hline 多样性指数 & $\mathrm{D}_{2-1}$ & $\mathrm{D}_{2-2}$ & $\mathrm{D}_{2-3}$ & $\mathrm{D}_{3-1}$ & $\mathrm{D}_{3-2}$ & $\mathrm{D}_{4-2}$ & $\mathrm{D}_{6}$ & $\mathrm{D}_{7}$ \\
\hline$H^{\prime}$ & 3.67 & 3.64 & 3.90 & 3.86 & 3.71 & 3.48 & 3.63 & 3.60 \\
$J$ & 0.63 & 0.64 & 0.69 & 0.69 & 0.64 & 0.61 & 0.66 & 0.64 \\
$d$ & 4.12 & 3.88 & 3.78 & 3.61 & 3.99 & 3.72 & 3.37 & 3.56 \\
\hline
\end{tabular}
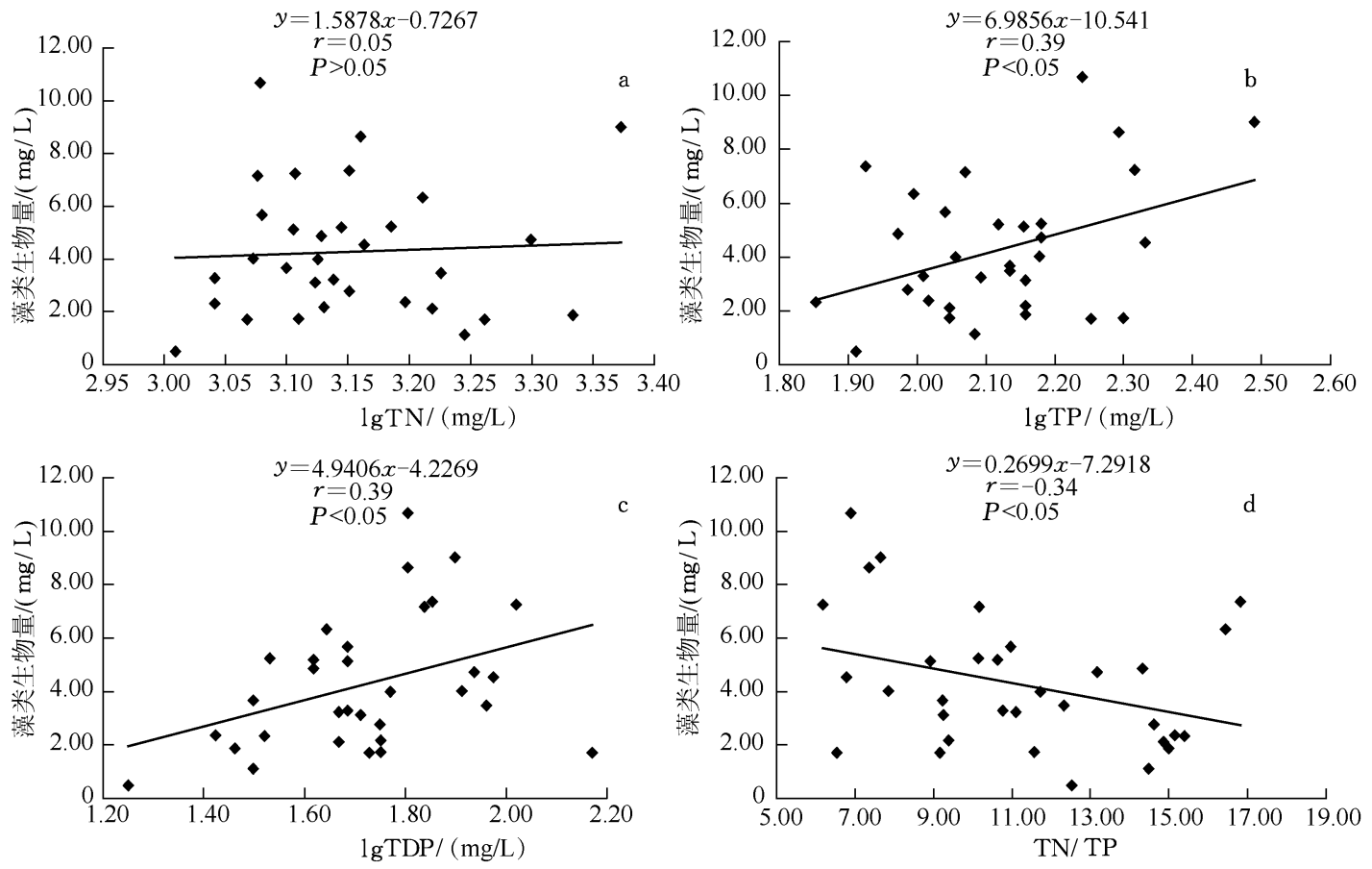

图 7 生态拦截沟中藻类生物量与 $\lg \operatorname{TN}(\mathrm{a}) 、 \lg \mathrm{TP}(\mathrm{b}) 、 \lg \operatorname{TDP}(\mathrm{c})$ 和 $\mathrm{TN} / \mathrm{TP}(\mathrm{d})$ 之间的关系 $(n=32)$

Fig. 7 The relationships between $\lg \mathrm{TN}(\mathrm{a}), \lg \mathrm{TP}(\mathrm{b}), \lg \mathrm{TDP}(\mathrm{c}), \mathrm{TN} / \mathrm{TP}(\mathrm{d})$ and the algae biomass in the ecological interception ditch

\section{3 讨论}

\section{1 生态拦截沟对营养盐的削减特点}

以前对农田生态拦截沟的研究通常关注的是其减缓水速, 促进水流所携带颗粒物质的沉淀和营养物质 的拦截 ${ }^{[3,8]}$. 巢湖流域水稻田中大量化肥的施用及降雨可造成径流中严重的氮、磷营养盐面源污染 ${ }^{[24]}$. 本研 究中, 农田面源污水中的氮、磷营养盐含量经生态拦截沟拦截后显著下降, 这说明农田生态拦截沟能够有效 地截流水稻田中氮、磷营养盐这一潜在的面源污染. 同时, 水体中总溶解磷浓度的大幅度下降表明农田生态 拦截沟中的水生植物能有效地吸收和利用水体中总溶解磷. 一般认为, 农田藻类能使结合态磷变为可溶解 性磷, 以提高磷肥料利用效率 ${ }^{[25-26]}$. 而水生植物的种植和培养可以抑制农田藻类利用磷源的能力, 进而大量 拦截水体中的可溶解性磷, 造成水体中总溶解磷浓度的大幅度下降. 这些现象都表明水生植物对农田面源 污水中的氮、磷营养盐的直接吸收和利用是生态拦截的主要形式 ${ }^{[27]}$. 而水生植物拦截的泥沙中氮、磷营养盐 较低, 占水体总氮、磷营养盐含量的比例也低 ${ }^{[28]}$. 另外, 农田生态拦截沟的铵态氮含量出现了轻微的上升. 一般 认为, 农田藻类能促进尿素的水解并吸收利用 $\mathrm{N}$ 素促进自身生长, 进而促进稻田氨挥发并由此造成 $\mathrm{NH}_{4}^{+}-\mathrm{N}$ 浓 度下降 ${ }^{[26,29]}$. 农田生态拦截沟建立后, 生态拦截沟中的水生植物就可以与农田藻类竞争作为 $\mathrm{N}$ 汇, 从而减少 
农田面源污水中的氨挥发损失 ${ }^{[26]}$, 因此, 铵态氮含量出现轻微上升.

\section{2 生态拦截沟中的浮游植物优势种类及其生态分类}

本研究中, 生态拦截沟中浮游植物的优势种类变化不大. 主要表现为水体中 $\mathrm{C}$ 类进攻策略型、 $\mathrm{S}$ 类进取 策略型和 $\mathrm{R}$ 类协调策略型藻类的共存. 其中, 藻类优势种类主要为 $\mathrm{C}$ 类进攻策略型种类 Cyclotella、Tetraëdron 和 $\mathrm{S}$ 类进取策略型种类 Microcystis, 此外, $\mathrm{R}$ 类协调策略型藻类 Oscillatoria 也占有一定比例. C 类进攻型策略 型藻类的代表种类是 Cyclotella、Tetraëdron 和 Coelastrum. 其中,Cyclotella ( A 族) 适合水体上下活动剧烈、硝态 氮变化不大的水体. 而在硅元素耗尽、稳定分层的水体中, Cyclotella 会迅速减少 ${ }^{[30]}$. 而 Tetraëdron ( $\mathrm{J}$ 族) 的特 点是无鞭毛, 不能运动, 常出现在浅水水体中 ${ }^{[12,31]}$. 生态拦截沟中 $\mathrm{S}$ 类进取策略型的代表种类是 Microcystis, $\mathrm{S}$ 类进取策略型藻类具有温度和光照适应性强, 适合在低 $\mathrm{CO}_{2} /$ 高 $\mathrm{pH}$ 、低 TN/TP、低无机氮条件下生长, 并且 能沉降到底泥中越冬等特点. 我国湖泊重建水生态系统后 $\mathrm{C}$ 类进攻策略型藻类如隐藻和硅藻常常取代 $\mathrm{S}$ 类 进取策略型的蓝藻而在水体中占优势 ${ }^{[13,32]}$. 本研究中, 生态拦截沟中水体具有浅、上下活动剧烈、氮磷营养 丰富的特点. 而 $\mathrm{C}$ 类进攻策略型藻类和 $\mathrm{S}$ 类进取策略型藻类都具有生长速率快、在水层中迁移能力强、获取 营养的能力较强等特点 ${ }^{[33-34]}$. 因此生态拦截沟中主要表现为绿藻和蓝藻 (主要属 $\mathrm{C}$ 类和 $\mathrm{S}$ 类藻类) 在此富营 养化水体占统治地位, 而 $\mathrm{R}$ 类协调策略型藻类占辅助地位. 藻类生物多样性研究表明,生态拦截沟中的水体 处于清洁或寡污型水平, 仅在夏季的 7 月份出现了轻微的水体污染. 在各个不同的植物培植区中, 藻类生物 多样性差异不明显. 而生态拦截沟中的藻类生物多样性主要受季节变化影响, 这与辛艳萍等研究物种季节 变化的优势情况较吻合 ${ }^{[35]}$. 水生植被的修复常常会带来藻类种类数和生物多样性的上 升 $^{[36]}$, 本研究中由于 水体保持流动性, 因此藻类种类数目和生物多样性的上升不明显. 浮游植物群落结构未能有所改善, 种类数 和多样性指数均未得到提高.

\section{3 生态拦截沟中水体由藻型稳态向草型稳态转变的决定因素}

实践表明,在较高氮、磷等营养盐水平下, 存在多种结构的水生态系统, 特别是有明显差异的藻型浊水 态和草型清水态两种较稳定的水生态系统 ${ }^{[4,19]}$. 实现水体由藻型浊水稳态向草型清水稳态转变是很多生态 工程的最终目的 ${ }^{[10,18,37]}$. 本研究中, 生态拦截沟中蓝藻生物量和在藻类群落中的比重并未下降. 造成这一结 果的原因有很多: 首先, 生态拦截沟中植被不具备很强的遏制蓝藻的能力, 以前的研究发现农田中的水稻常 表现出较强的抑制蓝藻生长的作用 ${ }^{[38]}$, 所以普通农田中的蓝藻种类和生物量均不高 ${ }^{[14]}$, 一部分农田中甚至 有意识培植固氮蓝藻以提高农田的氮肥利用率 ${ }^{[26]}$. 而生态拦截沟中的水生植物对蓝藻的遏制作用不强 ${ }^{[7]}$, 这就使得蓝藻从稻田进人生态拦截沟后生长不再受抑制, 并造成生态拦截沟出水口中蓝藻比例较进水口 高. 其次,生态拦截沟中高氮、磷营养盐水平支持了蓝藻的生长, 当水体中的总磷超过 $100 \mu \mathrm{g} / \mathrm{L}$ 时, 水生生态 系统常处于浮游藻类占优势的浊水稳态; 而当总磷低于 $30 \mu \mathrm{g} / \mathrm{L}$ 时, 水体常处于以沉水植被占优势的清水稳 态; 当总磷为 $30 \sim 100 \mu \mathrm{g} / \mathrm{L}$ 时, 水体可为浊水稳态, 也可为清水稳态 ${ }^{[39]}$. Meijer 等指出要保持水生态系统长 期稳定性, 应在水体总磷浓度小于 $100 \mu \mathrm{g} / \mathrm{L}$ 下种植沉水植物, 稳定水体的清水状态 ${ }^{[40]}$. 陈开宁等的研究也 表明在总磷超过 $100 \mu \mathrm{g} / \mathrm{L}$ 的水体中, 利用水生植被生态重建区将水生生态系统从藻类占优势的浊水稳态转 变为以水生高等植物占优势的清水稳态至少需要 2 年 ${ }^{[10]}$. 此外, 水体中内源性磷的释放, 环境中的光强、温 度和 $\mathrm{pH}$ 值等物理因素和水体中浮游动物的摄食作用等都可能影响生态拦截沟中的蓝藻生物量和其在藻类 群落中的比重 ${ }^{[5,15,37]}$. 因此, 若要利用生态拦截沟中的水生植物实现水体由藻型稳态向草型稳态的转换, 至 少需要从以下两方面对生态拦截沟的设计进行改进:1) 在生态拦截沟的设计中,增加氮、磷削减的环境工 程, 将水体的氮、磷含量削减到稳态转换阈值 $100 \mu \mathrm{g} / \mathrm{L}$ 以下, 再进行生态拦截, 会对蓝藻发挥遏制作用. 2) 生态拦截沟的水生高等植物的笁选上, 多使用具有克藻效应的水生植物, 加强水生植物对蓝藻的遏制作用. 从而实现巢湖流域蓝藻的控制和水生生态系统由藻型浊水态向草型清水态的稳态转变.

\section{4 生态拦截过程中浮游植物与营养盐之间的相互关系}

本研究中藻类的种类分布受营养盐的影响不大, CCA 分析表明, 营养盐对藻类的种类分布总解释度不 高, 这可能与生态拦截沟中的水流、沉积物再悬浮和水生植物的克藻效应有关 ${ }^{[8,41]}$. 同时, CCA 分析发现 TN/ $\mathrm{TP}$ 对藻类的种类分布有较高的解释率, 而且水体中浮游植物生物量与总磷对数和总溶解磷对数呈显著的正 相关关系, 可见生态拦截沟中的藻类主要表现为磷限制, 降低水体中的生物有效利用磷浓度有助于浮游植 
物生物量的控制 ${ }^{[42]}$. 此外, 水体中不同形态磷的存在也支持了生态拦截沟中浮游植物的生长 ${ }^{[42]}$, 而生态拦截 沟中绿藻在藻类群落中占有比重的下降可能与浮游动物的摄食作用有关 ${ }^{[5]}$. 以前的研究表明水体中 TN/TP 较 低时, 蓝藻的生物量和蓝藻在藻类群落中的比重就较高 ${ }^{[16-17]}$. 而 Smith 的 TN/TP 理论也认为微囊藻在低 TN/ TP 下容易占优势 ${ }^{[43]}$. 本研究中水体中的氮磷比保持在 10:1 左右. 同时, 水体中的 TN/TP 与藻类生物量表现出 的比较明显的负相关说明生态拦截沟中的低 TN/TP 不利于水体中的藻类控制. 而 Bulgakov 等总结的实验结果 认为, 高的 $N: P(20: 1 \sim 50: 1)$ 有助于绿藻的发展; 当 $\mathrm{N}: \mathrm{P}$ 下降到 5:1 10:1 时, 常常导致蓝藻占优势 ${ }^{[17]}$. 因此, 要实现生态拦截沟中藻类的控制应优先降低水体中的总磷和总溶解磷浓度, 并提高水体中的氮磷比.

\section{5 总结}

对巢湖流域的农业非点源污染应用最佳管理措施 (BMPs) 控制, 可以通过建立生态林、沿湖缓冲带、湿 地及多水塘等系统控制农业面源污染物的迁移转化. 同时可采取底泥清淤、生物操控等水体生态修复方法 实现水体营养盐内源控制 ${ }^{[41,44]}$. 本研究表明, 克藻作用强和磷吸附能力强的水生植物对降低农田污水中的 营养盐面源污染和藻类控制有至关重要的作用. 农业面源污水中的藻类营养盐限制主要为磷限制, 削减农 田径流的磷含量是控制巢湖流域水体富营养化和遏制蓝藻水华的关键环节.

致谢: 安徽省巢湖市农业生态环保站的周世春、徐宏军等同志和安徽农业大学资源与环境学院的李为花、黄 开胜、王情、夏云、鲍俊杰、孙当歌等同学协助完成部分野外采样工作,在此一并表示感谢!

\section{4 参考文献}

１１］殷福才,张之源. 巢湖富营养化研究进展,湖泊科学, 2003,15(4):377-384.

[2] 刘 洁, 马友华, 石润圭等. 巢湖流域农业面源污染现状分析及防治对策思考. 农业环境与发展, 2008, 25(6): 13-16.

[ 3 ] 韩例娜, 李裕元, 石 辉等. 水生植物对农田排水沟渠氮磷迁移生态阻控效果比较研究. 农业现代化研究, 2012,33 (1) $: 117-120$.

[ 4 ] 兴培民, 李裕红, 张晋芳等. 用生态修复调控浮游植物种群局部控制富营养化一以贵州红枫湖水质生态修复工 程为例. 湖泊科学, $2012, \mathbf{2 4}(4)$ : 503-512.

[ 5 ] Benndorf J, Böing W, Koop J et al. Top-down control of phytoplankton: the role of time scale, lake depth and trophic state. Freshwater Biol, 2002, 47: 2282-2295.

[ 6 ] Chen JZ, Liu ZL, Ren GJ. Control of Microcystis aeruginosa TH01109 with batangas mandarin skin and dwarf banana peel: technical note. Water $S A, 2004, \mathbf{3 0}(2): 279-282$.

[ 7 ] 边归国, 赵卫东, 达 来. 农副产品及废弃物化感抑藻作用的研究与机理. 内蒙古农业大学学报, 2012, 33(2): 268-273.

[ 8 ] 杨林章, 周小平, 王建国等. 用于农田非点源污染控制的生态拦截型沟渠系统及其效果. 生态学杂志, $2005, \mathbf{2 4}$ (11) : :1371-1374.

[ 9 ] Qi HH, Altinakar MS. Vegetation buffer strips design using an optimization approach for non-point source pollutant control of an agricultural watershed. Wat Res Manag, 2011, 25(2) : 565-578.

[10］陈开宁, 周万平, 鲍传和等. 浮游植物对湖泊水体生态重建的响应一以太湖五里湖大型围隔示范工程为例. 湖 泊科学, $2007,19(4): 359-366$.

[11] 刘娅琴, 邹国燕, 宋祥甫等. 富营养水体浮游植物群落对新型生态浮床的响应. 环境科学研究, 2011, 24(11): 1233-1241.

[12] Reynolds CS. Vegetation process in the pelagic: a model for ecosystem theory. In: Kinne 0 ed. Excellence in ecology. Oldendorf: ECI, 1997.

[13] 陈 亮, 张修峰, 刘正文. 惠州西湖浮游植物群落对生态系统修复的响应. 武汉植物学研究, 2010,28(4):453-459.

[14] 刘蔚秋,王永繁, 徐润林. 生物防治稻田与普通稻田水体中浮游植物的生态特征研究. 应用生态学报, 2001, 12 (1) : 59-62.

[15] Deng DG, Xie P, Zhou Q et al. Temporal and spatial variations of phytoplankton in a large shallow Chinese lake with dense cyanobacterial blooms. J Integr Plant Biol, 2007, 49: 409-418.

[16] Reynolds CS. No-determinism to probability, or N:P in the community ecology of phytoplankton. Archiv fuir Hydrobiologia, 
$1999,146: 23-35$.

[17] Bulgakov NG, Levich AP. The nitrogen to phosphorus ratio as a factor regulating phytoplankton community structure. Archiv fiur Hydrobiologia, 1999, $146: 3-22$.

[18］柴 夏,刘从玉, 陈 清等. 生态修复对浮游植物种群结构的影响. 环境科技, 2008, 21(5) :17-20.

[19] Schefer M, Carpenter SR, Foley JA et al. Catastrophic shifts in ecosystems. Nature,2001, 413:591-596.

[20] Ebina J, Tsutsui T, Shirai T. Simultaneous determination of total nitrogen and total phosphorus in water using peroxodisulfate oxidation. Water Res, 1983, 17: 1721-1726.

[21] 胡鸿均,魏印心. 中国淡水藻类一一系统、分类及生态. 北京: 科学出版社,2006: 1-1023.

[22］金相灿,屠清瑛. 湖泊富营养化调查规范. 北京: 中国环境科学出版社, 1990,286-302.

[23] Jongman RH, ter Braak CJ, Van Tongeren OF. Data analysis in community and landscape ecology. Cambridge: Cambridge University Press, 1995: 91-173.

[24] 王桂苓,马友华,孙兴旺等. 巢湖流域麦稻轮作农田径流氮磷流失研究. 水土保持学报, 2010,24(2): 6-10,29.

[25] Saha KC, Panigrahj BC, Singh PK. Blue-green algae or Azolla addition on the nitrogen and phosphorus availability and redox potential of a flooded rice soil. Soil Biol Biochem,1982,14:23-26.

[26] 张启明,铁文霞,尹 斌等. 藻类在稻田生态系统中的作用及其对氨挥发损失的影响. 土壤,2006,38(6):814-819.

[27] 晏维金, 孙 誉,尹澄清等. 磷氮在水田湿地中的迁移转化及径流流失过程. 应用生态学报, 1999,10(3): 312-316.

[28 ] Jiang CL, Fan XQ, Cui GB et al. Removal of agricultural non-point sources pollutants by ditch wetlands: implications for lake eutrophication control. Hydrobiologia, 2007, 581(1) : 319-327.

[29] Savant NK, James AE, McClellan GH. Effect of soil submergence on urea hydrolysis. Soil Sci, 1985,140 :81-88.

[30] Reynolds CS. Phytoplankton designer- or how to predict compositional responses to trophic-state change. Hydrobiologia, $2000,424: 147-152$.

[31 ] Reynolds CS, Huszar V, Kruk C et al. Towards a functional classification of the freshwater phytoplankton. J Plank Res, $2002,24: 417-428$.

[32] 路 娜, 尹洪斌, 邓建才等. 巢湖流域春季浮游植物群落结构特征及其与环境因子的关系. 湖泊科学, 2010,22 (6) : $950-956$.

[33] Elgavish GA, Halmann M, Berman T. Phosphorus utilization and storage in batch cultures of the dinoflagellate Peridininm cinctum F. westii. J Phycol, 1980 ,16:626-633.

[34] Zhang X, Xie P, Chen FZ et al. Driving forces shaping phytoplankton assemblages in two subtropical plateau lakes with contrasting trophic status. Freshwater Biol, 2007, 52 : 1463-1475.

[35] 辛艳萍, 韩博平,霄腊梅等. 两座抽水型水库蓝藻种群与微囊藻毒素的比较分析. 热带亚热带植物学报, 2010,18 (3) :224-230.

[36] 刘冬燕,赵建夫, 张亚雷等. 绥宁河生物修复中浮游植物的生态特征研究. 应用生态学报, 2005, 16(4): 703-707.

[37] Schefer M, Carpenter SR, Foley JA et al. Catastrophic shifts in ecosystems. Nature, 2001, 413:591-596.

[38 ] 张余霞, 张 玲, 张阳阳. 盐京九号水稻秸秆对铜绿微囊藻 (Microcystis aeruginosa) 抑制作用. 生态与农村环境学报, $2008,24(3): 60-63,80$.

[39］王海军,王洪铸. 富营养化治理应放宽控氮、集中控磷. 自然科学进展,2009,19(6) : 599-604.

[40] Meijer M, Hosper H. Effects of biomanipulation in the large and shallow lake Wolderwijd, the Netherlands. Hydrobiologia, 1997, 342 (43) : 335-349.

[41] James Z, Joseph CM. Detecting effects of Best Management Practices on rain events generating nonpoint source pollution in agricultural watersheds using a physically-based stratagem. J Great Lakes Res,2009,35 (Suppl. 1) : 37-42.

[42] 秦伯强,朱广伟. 长江中下游地区湖泊水和沉积物中营养盐的赋存、循坏及其交换特征. 中国科学: D 辑: 地球科 学, 2005, 32(2) : 1-10.

[43] Smith VH. Low nitrogen to phosphorus ratios favor dominance by blue-green algal biomass in lake phytoplankton. Science, 1983, 221 : 669-671.

[44] Lee MS, GeunAe P, Min JP et al. Evaluation of non-point source pollution reduction by applying Best Management Practices using a SWAT model and Quick Bird high resolution satellite imagery. J Environ Sci,2010,22(6) : 826-833. 